\title{
HEAVY THUNDERSTORMS ON THE POLISH-GERMAN LOWLANDS IN THE PERIOD 1951-2008 AND THEIR CIRCULATION CONDITIONS
}

\author{
LESZEK KOLENDOWICZ \\ Adam Mickiewicz University, Institute of Physical Geography and Environmental Planning, \\ Department of Climatology, Poznań, Poland
}

Manuscript Received: January 09, 2012

Revised Version: July 25, 2012

Kolendowicz L., 2012. Heavy thunderstorms on the Polish-German lowlands in the period 1951-2008 and their circulation conditions. Quaestiones Geographicae 31(3), Bogucki Wydawnictwo Naukowe, Poznań 2012, pp. 25-32. 7 Figs., 1 Tab. DOI 10.2478/v10117-012-0027-3, ISSN 0137-477X.

ABSTRACT. The aim of the study was an analysis of the impact of atmospheric circulation over the territory of Europe on the frequency of occurrence of heavy thunderstorms on German Lowlands and on Polish Lowlands in the period 1951-2008. The atmospheric circulation in days with investigated phenomena was illustrated as the averaged image of the atmospheric pressure field over Europe (sea level pressure and $500 \mathrm{hPa}$ geopotential heights). Heavy thunderstorm phenomena occur as a result of low pressure systems or low pressure troughs moving above investigated area and bringing cold air masses. Usually, the distribution of isobars at sea level indicates the occurrence of atmospheric fronts accompanying a low pressure system.

KEY WORDS: heavy thunderstorms, atmospheric circulation, Polish-German Lowlands

Leszek Kolendowicz, Institute of Physical Geography and Environmental Planning, Poznań, Adam Mickiewicz University, ul. Dziegielowa 27, 61-680 Poznań, Poland, e-mail: leszko@amu.edu.pl

\section{Introduction}

Thunderstorms belong to the numerous meteorological phenomena that pose a risk to man. Material losses caused by storms follow primarily from high-intensity electrical discharges, strong winds that accompany Cumulonimbus clouds, and intense precipitation which leads to local floods and hail (Barnes \& Newton 1986, Uman 1987). Strong thunderstorms recently occurring in many German and Polish cities and their economic effects justify research into thunderstorms in that area and into their underlying synoptic reasons.
The atmospheric circulation, observed on a synoptic scale, and atmospheric processes with a mezoscale coverage, are responsible for the occurrence of thunderstorm phenomena. The said circulation processes, determining the transport of humidity and heat, also influence the intensity and duration of thunderstorm phenomena. Numerous authors occupied with thunderstorm activity have noted the strong connections between this activity and specific synoptic situations (Schaefer et al. 1986, Brazdil 1998, BielecBąkowska 2003). 


\section{Methods}

The aim of the present study was an analysis of the impact of atmospheric circulation over the territory of Europe on the frequency of occurrence of heavy thunderstorms on German Lowlands and on Polish Lowlands in the period 1951-2008.

While performing an analysis of that research problem, data on the occurrence of days with thunderstorms in the period 1951-2008 from 31 weather stations located in the north of Poland and Germany were taken into consideration. At the beginning the thunderstorm activity on the research area was characterized. In the next part of the study using the Ward's hierarchical clustering method, four regions were distinguished in the studied area, characterized by a similar distribution of days with thunderstorms at the particular weather stations during an averaged year. Subsequently, for each region days were determined when thunderstorms had been observed simultaneously at all the analyzed weather stations.. The observations of thunderstorm phenomena at all stations of a given region on a given day attested to high intensity of thunderstorms and a high risk of material losses that may be caused by the accompanying phenomena.

The other part of the study presents the averaged image of the atmospheric pressure field over Europe typical of the occurrence of heavy thunderstorm days in each region. In order to describe the mean atmospheric circulation in days with heavy thunderstorms, the sea level pressure (SLP) and $500 \mathrm{hPa}$ geopotential heights data of a mean day were selected from the National Cent- ers for Environmental Prediction (NCEP) - National Center for Atmospheric Research (NCAR) reanalysis data for the period 1971-2007 (Kalnay et al., 1996). The synoptic area encompasses the region $35-70^{\circ} \mathrm{N}$ latitude by $35^{\circ} \mathrm{W}-40^{\circ} \mathrm{E}$ longitude with $5^{\circ}$ resolution. Composite maps of the SLP and $500 \mathrm{hPa}$ geopotential heights means were constructed for the days where thunderstorms occurred in 100\% considered in the research meteorological stations in distinguished regions.

In order to facilitate the objective of the comparison of the averaged baric distribution of sea level pressure (SLP) and height of the $500 \mathrm{hPa}$ geopotential, the author constructed maps of the average distribution of atmospheric pressure for sea level (SLP) and the heights of the $500 \mathrm{hPa}$ geopotential for the season from May to September. Anomalies of the distribution of pressure at sea level (SLP) and at the height of the $500 \mathrm{hPa}$ geopotential were calculated as the difference between the mean from this season $r$ and the mean characterising the days with $100 \%$ of the thunderstorm frequency. The pressure distribution maps thus obtained, both for sea level and the height of the $500 \mathrm{hPa}$ geopotential, together with the anomalies of the mean season from May to September allow us to better understand the circulation patterns underlying the occurrence of heavy thunderstorm phenomena.

\section{Results and discussion}

The average number of days with thunderstorms in the year increases from the NW to the

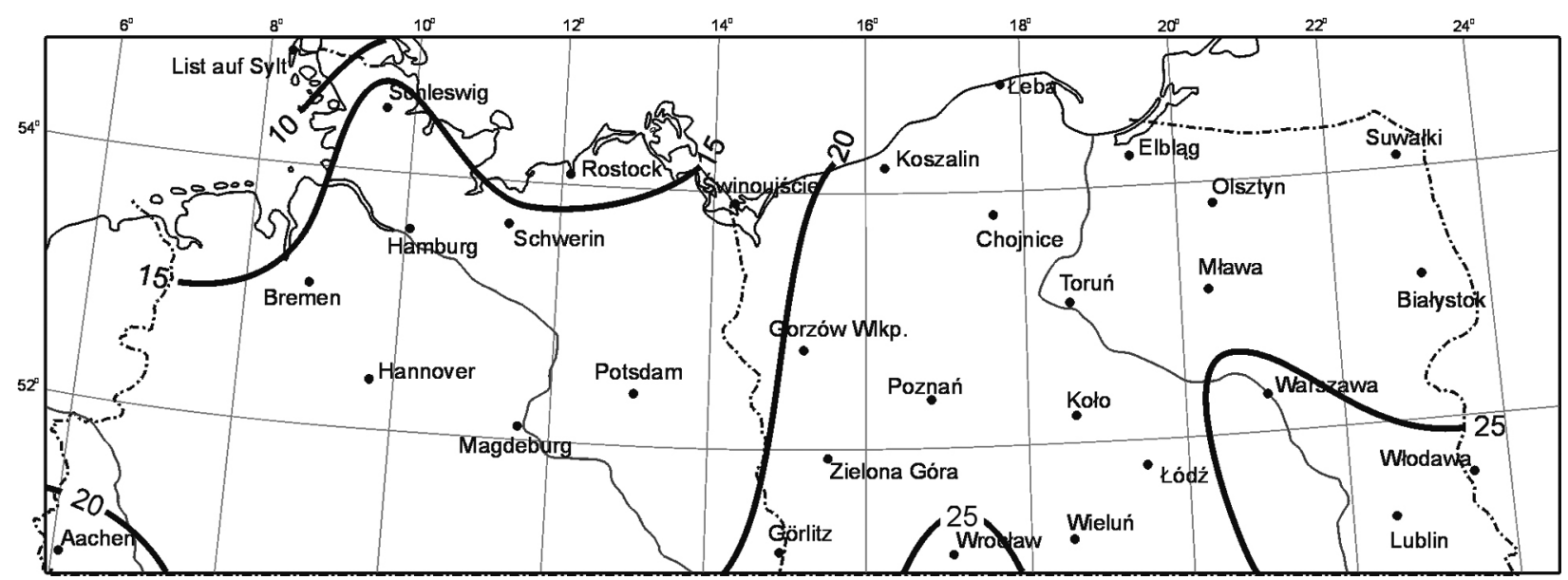

Fig. 1. The average number of days with thunderstorms in the year. Data from the period 1951-2008. 

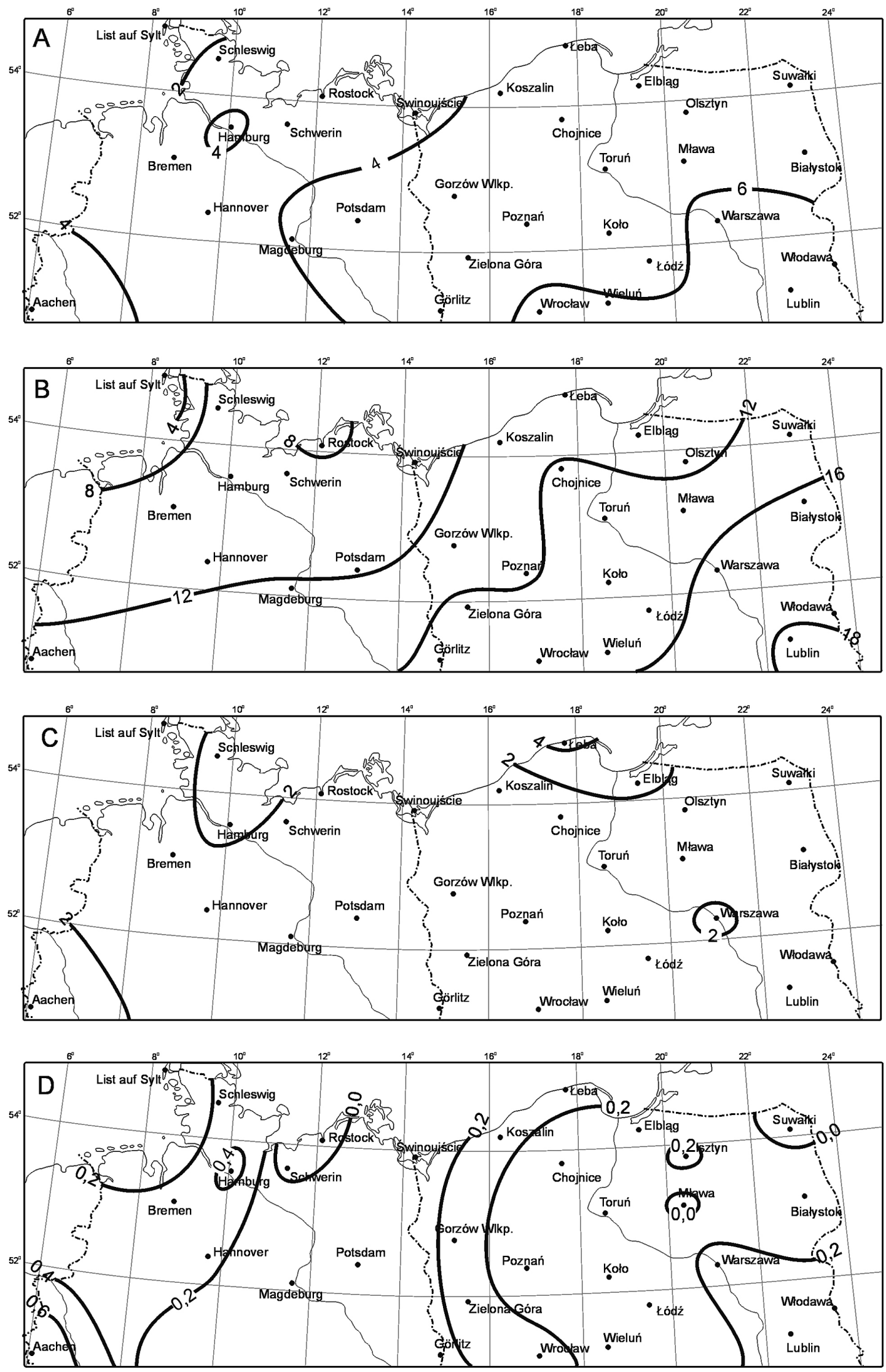

Fig. 2. The frequency of days with thunderstorms in seasons of the year. A - spring, B - summer, C - autumn, D - winter Data from the period. 1951-2008. 


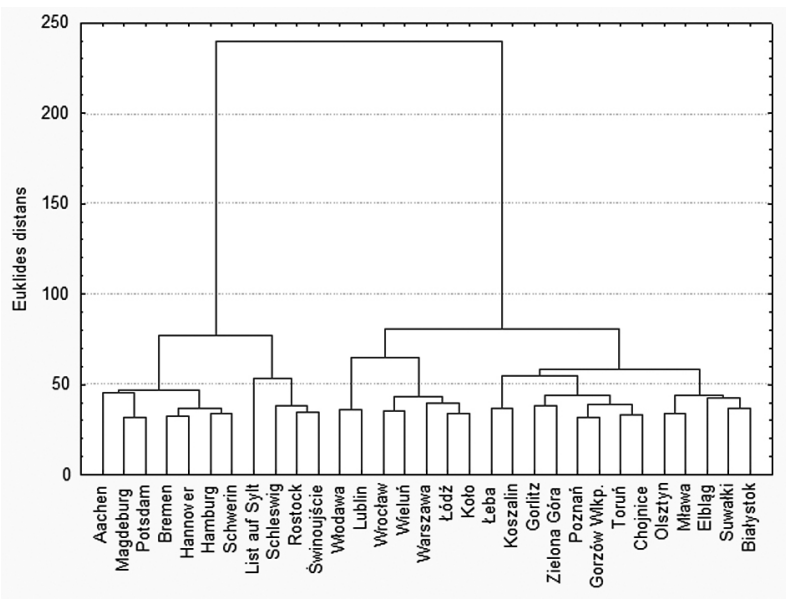

Fig. 3. The grouping of meteorological stations.

SE of the researched area, from approximately 10 in the northern part of Germany to more than 25 in the south-eastern part of Poland (Fig. 1). This trend is apparent both in spring and summer, whereas in autumn and winter the distribution of the frequency of occurrence of days with thunderstorms is very even.

Days with thunderstorms most frequently occur in summer, from approximately 4 in the NW to more than 18 in the SE of the researched area. In spring, the analysed frequency is smaller and ranges from approximately 2 days in north Germany to more than 6 in the SE part of Poland. In autumn, storm activity decreases considerably over the researched area, ranging from - on average - 2 days to 4 days with the analysed phenomenon. Days with thunderstorms are least frequent in winter, from 0 to more than 3 during the researched period of 58 years (Fig. 2).
Table 1 . The frequency of days with thunderstorms in distinguished regions in months, seasons of the year and in the year. Data from the period 1951-2008.

\begin{tabular}{|c|c|c|c|c|}
\hline \multirow{2}{*}{ Months } & \multicolumn{4}{|c|}{ Regions } \\
\cline { 2 - 5 } & $\mathbf{1}$ & $\mathbf{2}$ & \multicolumn{1}{c|}{$\mathbf{3}$} & $\mathbf{4}$ \\
\hline 1 & 0.03 & 0.07 & 0.04 & 0.06 \\
\hline 2 & 0.04 & 0.14 & 0.05 & 0.11 \\
\hline 3 & 0.09 & 0.22 & 0.19 & 0.29 \\
\hline 4 & 0.46 & 0.82 & 1.06 & 1.32 \\
\hline 5 & 1.78 & 2.78 & 3.85 & 4.56 \\
\hline 6 & 2.31 & 3.72 & 4.78 & 5.47 \\
\hline 7 & 2.93 & 4.06 & 5.33 & 6.14 \\
\hline 8 & 2.53 & 3.51 & 4.27 & 4.78 \\
\hline 9 & 1.24 & 1.30 & 1.67 & 1.50 \\
\hline 10 & 0.36 & 0.30 & 0.35 & 0.26 \\
\hline 11 & 0.17 & 0.16 & 0.11 & 0.04 \\
\hline 12 & 0.06 & 0.06 & 0.04 & 0.03 \\
\hline spring & 2.33 & 3.83 & 5.09 & 6.17 \\
\hline summer & 7.78 & 11.30 & 14.40 & 16.40 \\
\hline autumn & 1.77 & 1.77 & 2.14 & 1.81 \\
\hline winter & 0.13 & 0.28 & 0.14 & 0.20 \\
\hline year & 12.00 & 17.20 & 21.70 & 24.60 \\
\hline
\end{tabular}

Following the grouping of stations using Ward's method (Fig. 3), we have arrived at a division of the researched area into four regions. The results of the regionalisation together with the distribution of meteorological stations considered in the study have been presented in Fig. 4. In each region, days with thunderstorms occur most frequently in July, and least frequently in December and January. The greatest storm activity occurs in region 4, located in the SE part of the researched area, with more than 24 days with storms throughout the year. The smallest activity, in turn, occurs in region 1, where on average 12

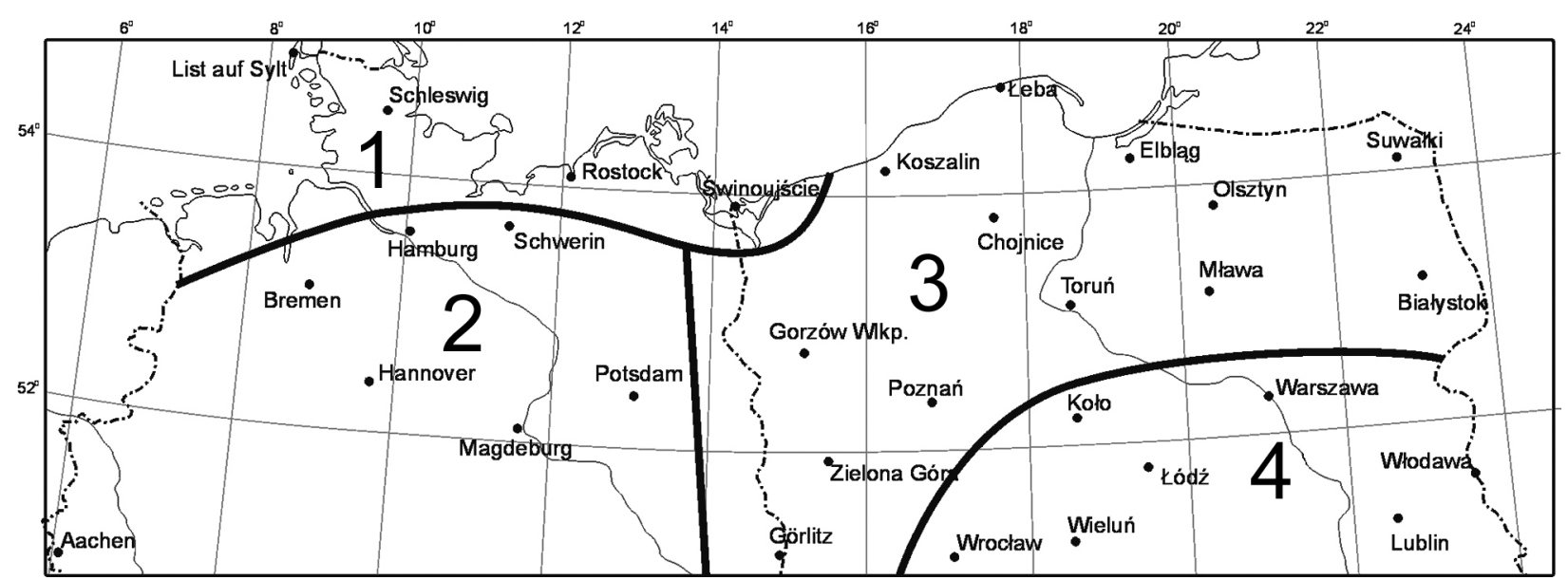

Fig. 4. The results of the regionalisation together with the distribution of meteorological stations. 

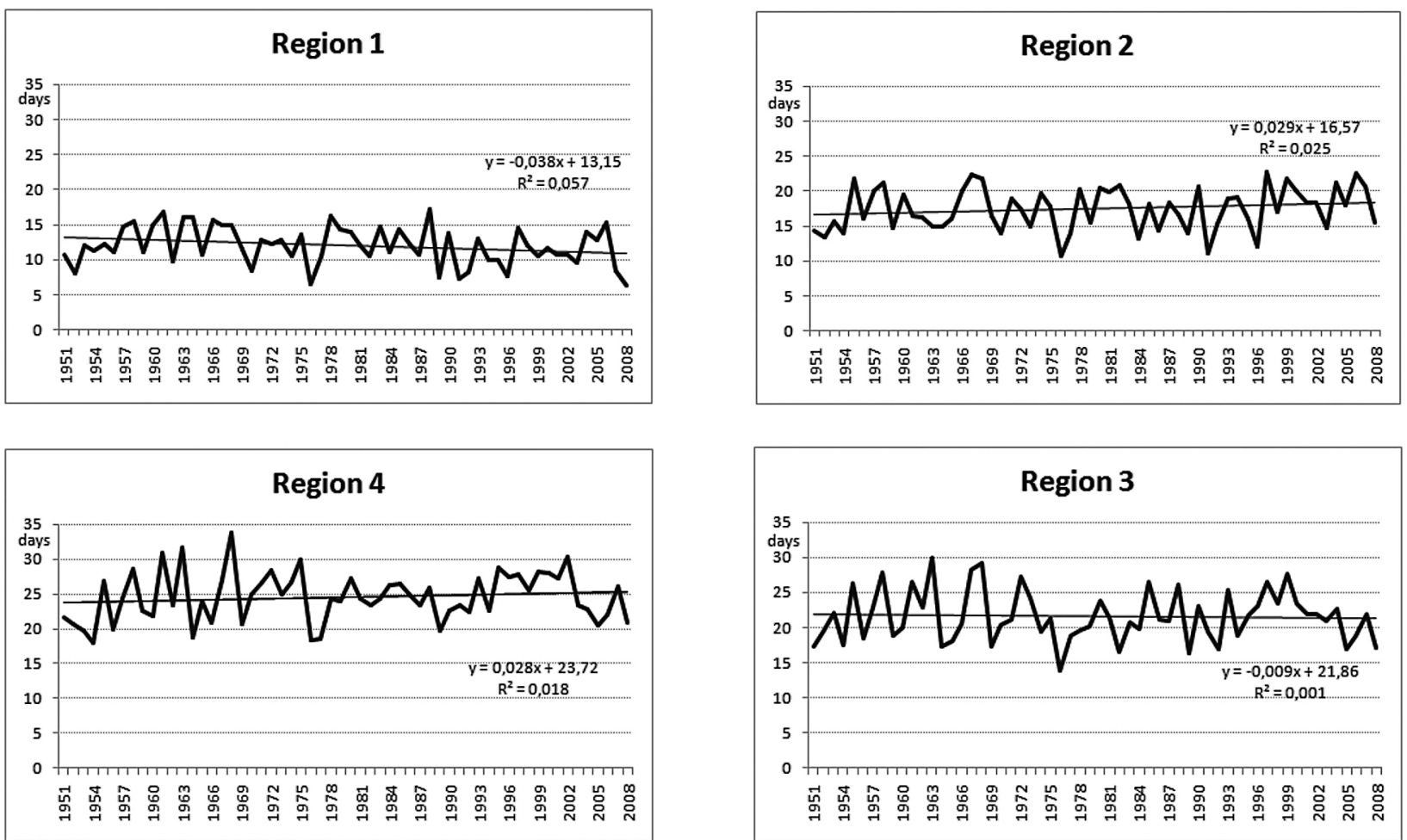

Fig. 5. The average multi-year courses of days with storms for distinguished regions. Data from the period 1951-2008.
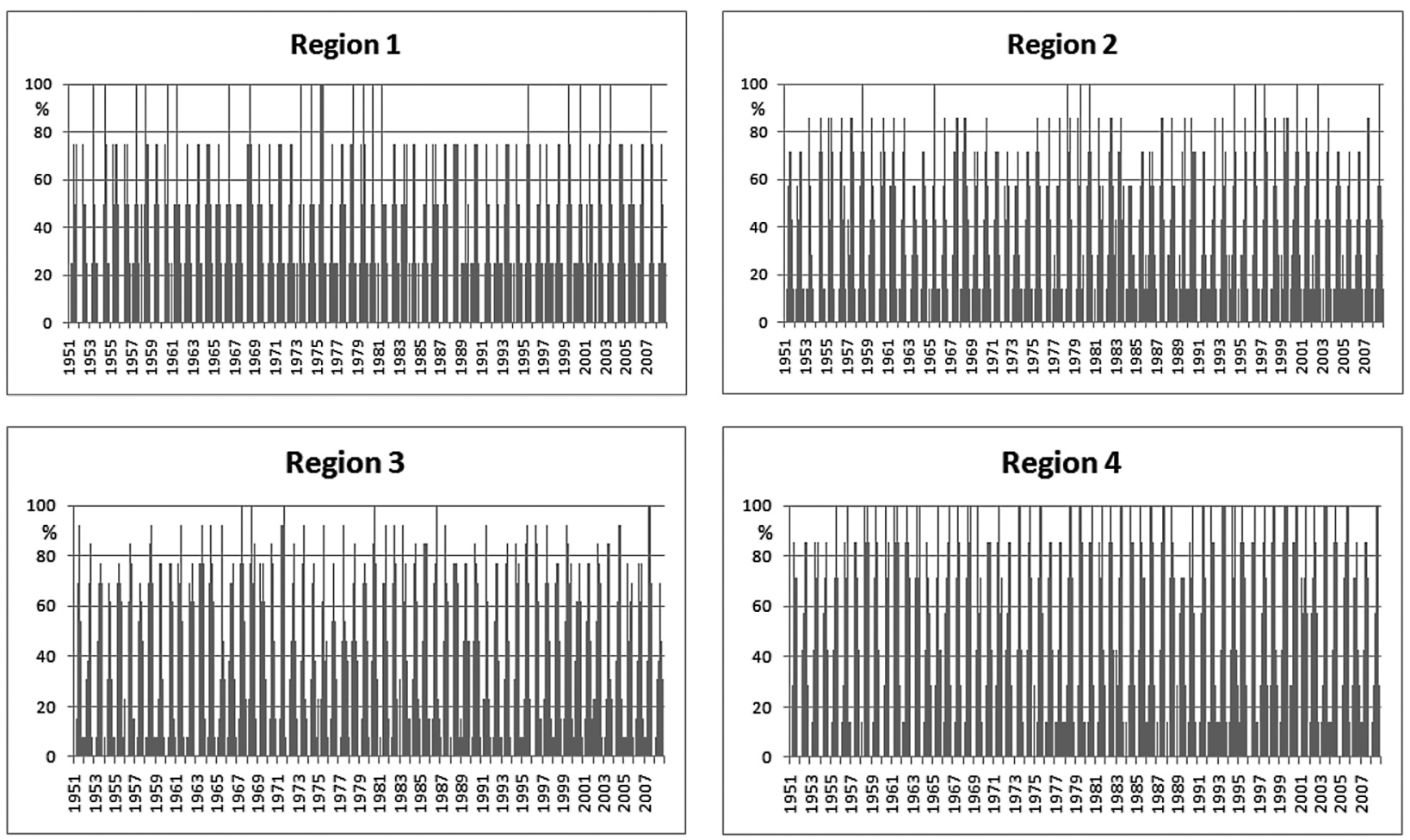

Fig. 6. The frequency of the simultaneous occurrence of days with thunderstorms in all stations in a given region.

days with thunderstorms are observed throughout the year (Tab. 1).

An analysis of the average multi-year courses of days with storms for individual regions (Fig. 5)

points to the increasing storm activity in regions 2 and 4 , and decreasing activity in regions 1 and 3 , however these trends - at a level of $p=0.05$ are not statistically significant. 

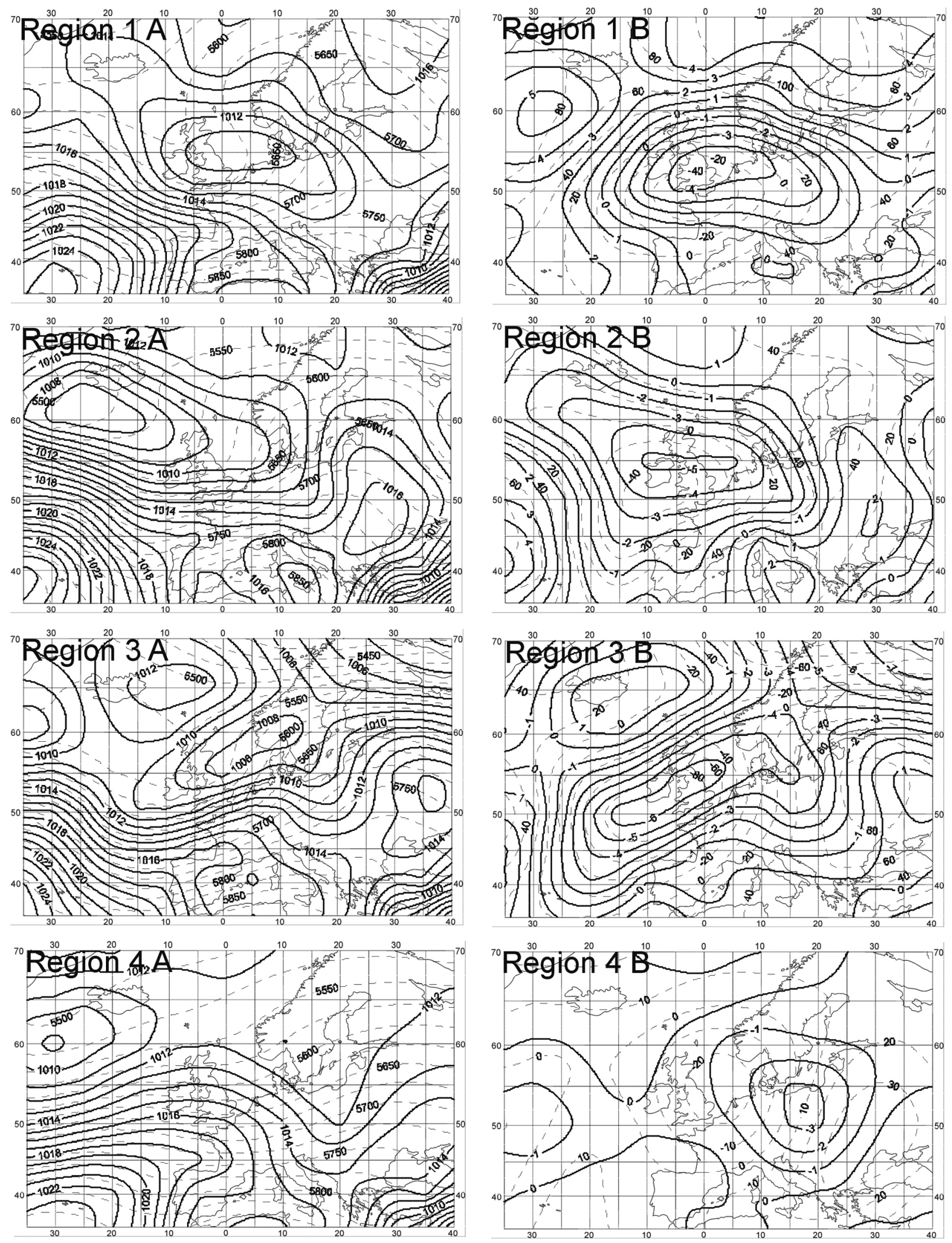

Fig. 7. The pressure distribution maps for sea level and the height of the $500 \mathrm{hPa}$ geopotential $-\mathrm{A}$, and the anomalies of the mean season from May to September - B for days with a simultaneous occurrence of thunderstorms in all stations in the distinguished regions. Data from the period 1971-2007. 
An analysis of the frequency of the simultaneous occurrence of days with thunderstorms in all stations in a given region points to considerably large differences in the frequency of occurrence of such instances. Over the researched period of 58 years, 11 were observed for region 1,10 for region 2 , only 7 for region 3 , while as many as 77 for region 4 (Fig. 6). The analysed days occurred only in the warm season of the year, from May to September.

The pressure distribution maps for sea level and the height of the $500 \mathrm{hPa}$ geopotential and the anomalies of the mean season from May to September for days with a simultaneous occurrence of thunderstorms in all stations in the distinguished regions has been presented in Figure 7. In region 1, analysed days with strong thunderstorms appear during the occurrence of a baric low with its centre over the North Sea, with pressure lower than the average for the period from May to September by more than $4 \mathrm{hPa}$. During this period, the isobaric surface of $500 \mathrm{hPa}$ is located some $20-40 \mathrm{~m}$ lower than on average, at a height of 5,700-5,650 $\mathrm{m}$ above sea level over the researched region. The characteristic rapid deflection of isobars forming into a low pressure embayment and the lowering of the isobaric surface of $500 \mathrm{hPa}$ points to the occurrence of a cold mass of air preceded by a cool atmospheric front over this part of Europe.

In region 2, the baric situation and the height at which the isobaric surface of $500 \mathrm{hPa}$ is located develop similarly to those observed in region 1 . The difference concerns the location of the centre of the low pressure system over the North Atlantic and the greater atmospheric pressure anomalies in the low.

For region 3, the low pressure centre with its centre over South Scandinavia plays a fundamental role, as does the atmospheric front zone - clearly visible due to the deflection of isobars - over the researched area, which precedes the mass of cool atmospheric air flowing in from the west.

For region 4, the baric situation of occurrence of violent thunderstorms is considerably similar. The difference in comparison with region 3 pertains to the occurrence of a negative pressure anomaly at sea level over the area of region 4 , and the smaller height anomalies of location of the isobaric surface of $500 \mathrm{hPa}$.

\section{Conclusions}

Heavy thunderstorm phenomena occur in the distinguished regions as a result of low pressure systems or low pressure troughs moving above them and bringing cold air masses. Usually, the distribution of isobars at sea level indicates the occurrence of atmospheric fronts accompanying a low pressure system. A cold air mass is always preceded by a warmer air mass which is clearly visible on the maps presenting the $500 \mathrm{hPa}$ isobaric level Geopotential height and its anomalies. In a majority of the analysed situations, we observed an elevated atmospheric pressure system to the east of the studied region, which supports the transport of warm air masses from the south of Europe over the studied area. The conditions of an occurrence of heavy thunderstorms on an investigated area are similar to observed on other part of Europe or in the central and eastern part of USA (Walkner 1992, Changnon 1998, 2001, Changnon \& Changnon 2001, Kolendowicz 2006).

\section{References}

BARNES S.N. \& NeWTON C.W., 1986. Thunderstorm in the synoptic setting. In: E. Kessler (ed.), Thunderstorm Morphology and Dynamics. University of Oklahoma. Vol. 1/2 of Thunderstorms: A Social, Scientific \& Technological Documentary: 75-112.

BIELEC-BĄKOWSKA Z., 2003. Long-term variability of thunderstorm occurrence in Poland in the 20th century. Atmospheric Research, 67-68: 35-52.

BRAZDIL R., 1998. Casovị a prostorovị analżza bourek, krupobitk a extrémnksch srịcek v ji_nks cịsti Moravy v obdobks 1946-1995. Meteorologicke Zpravy, 51: 45-52.

Changnon S.A., 1988. Climatography of thunder events in the conterminous United States. P. I: Temporal aspects. Journal of Climate, 1: 389-398.

Changnon S.A., 2001. Damaging thunderstorm activity in the United States. Bulletin of American Meteorological Society, 82: 597-608.

Changnon S.A. \& Changnon D., 2001. Long-term fluctuation in thunderstorm activity in the United States. Climate Change, 50: 489-503.

Kalnay E., Kanamitsu M., Kistler R., Collins W., Deaven D., Gandin L., Iredell M., SaHa S., White G., WoOllen J., ZhU Y., Leetmaa A., Reynolds R., Chelliah M., Ebisuzaki W., Higgins W., Janowiak J., Mo K.C., Ropelewski C., Wang J., JENne R. \& Joseph D., 1996. The NMC/NCAR 40-Year 
Reanalysis Project. Bulletin of American Meteorological Society, 77: 437-471.

KolENDOWICZ L., 2006. The influence of synoptic situations on the occurrence of days with thunderstorms during a year in the territory of Poland. International Journal of Climatology, 26: 1803-1820.

Schaefer J.T., Hoxit L.R. \& Chappell C.F., 1986. Thunderstorms and their mesoscale enviroment. In: E. Kessler (ed.), Thunderstorm Morphology and Dynamics. University of Oklahoma Press Norman and London. Vol. 1/2 of Thun- dermstorms: A Social, Scientific \& Technological Documentary: 113-132.

UMAN M.A., 1987. The lightning discharge. International Geophysics Series. Monographs and Textbooks, Vol. 39. Academic Press, Inc. Orlando, San Diego, New York, Austin, Boston, London, Sydney, Tokyo, Toronto.

WALKNER A., 1992. Grossräumige Austauschprozesse der Atmosphäre als Ursache von Starkgewittern. Physiche Geographie, 35. Zürich. 